\title{
Correction to: Core Affect Dynamics: Arousal as a Modulator of Valence
}

Valentina Petrolini ${ }^{1} \cdot$ Marco Viola $^{2}$

Published online: 30 May 2020

(C) Springer Nature B.V. 2020

\section{Correction to: Review of Philosophy and Psychology https://doi.org/10.1007/s13164-020-00474-w}

The initial online publication contained several typesetting errors. The original article has been corrected.

Publisher's Note Springer Nature remains neutral with regard to jurisdictional claims in published maps and institutional affiliations.

The online version of the original article can be found at https://doi.org/10.1007/s13164-020-00474-w

Valentina Petrolini

valentina.petrolini@ehu.eus

Marco Viola

marco.viola@unito.it

1 University of the Basque Country (UPV/EHU), Centro de Investigación Micaela Portilla, Justo Vélez de Elorriaga Kalea, 1, 01006 Vitoria-Gasteiz, Spain

2 Department of Philosophy and Education, University of Turin, via Sant'Ottavio, 20, 10124 Turin, Italy 